\title{
Evaluation of lablab bean (Lablab purpureus (L.) Sweet) sprout milk fortificated with eggshell extracted calcium
}

\section{DAVID TJANDRA NUGRAHA ${ }^{1 *}$ and FRANSISCUS SABATINO BATA ${ }^{2}$}

\author{
${ }^{1}$ Faculty of Food Science, Szent István University Budapest, Villányi út 35-43, 1118, Budapest, Hungary \\ ${ }^{2}$ Faculty of Agricultural Technology, Widya Mandala Catholic University, Dinoyo st. 42-44, 60118, \\ Surabaya, Indonesia
}

\section{CONFERENCE FULL PAPER}

Received: August 11, 2020 • Accepted: September 29, 2020

Published online: November 12, 2020

(C) 2020 The Author(s)

\begin{abstract}
Lablab purpureus (L.) Sweet is a common bean in Asia. High protein content and similar amino acid composition with soybean makes good substitutes against dependency on imported products in Asian countries. One example of a bean product is vegetable milk. Fortification is executed to create a product, which compels our diet. Many people experience low protein and mineral intake from food. Fortification of plant origin products utilizing food waste by-products, namely eggshell waste by-product, may give an opportunity on this field. Milk created using beans is processed immediately. However, physiological process (germination) is capable of increasing its nutrition quality. This research focuses on variation of germination time: $0,12,24,36$, and $48 \mathrm{~h}$. Protein digestibility is selected as the main parameter to consider the time. Protein, and mineral content, $\mathrm{pH}$, and total soluble solid content of the milk are analyzed. Germination time of $36 \mathrm{~h}$ establishes sprout with digestible protein of $13.36 \pm 0.59 \mathrm{~g} / 100 \mathrm{~g}$, milk protein content of $7.21 \pm 0.06$ $\mathrm{g} / 100 \mathrm{~g}, \mathrm{pH}$ of $6.74 \pm 0.17$, and total soluble solid content of 19.0 brix. The addition of eggshell extracted calcium as calcium fortification is $2 \% \mathrm{w} / \mathrm{v}$, which resulted in mineral content of $276 \pm 0.13 \mathrm{mg} / 100 \mathrm{~g}$.
\end{abstract}

\section{KEYWORDS}

vegetable milk, fortification, germination

*Corresponding author. E-mail: dtdavidtjandra@gmail.com 


\section{INTRODUCTION}

Lablab bean (Lablab purpureus (L.) Sweet) is a kind of legumes that is commonly found in Asia and has complete nutritional value. The aged lablab seed is often found to be dried and consumed (Salunke, 1985). Lablab bean has a high productivity rate with 6-10 ton per hectare yield, far more superior than the likes of soybean, which only yields 1.3 ton per hectare (Purseglove, 1981). Lablab bean contains high amount of carbohydrate, fiber, fat, amino acids, and trace minerals. The protein content of this bean is high (20-28\%) and one of the best source for iron mineral (155 mg/100 g bean) (Kay, 1979). The amount of protein in this bean does not differ too much with other high-protein beans such as soybean. Lablab bean has a very similar amino acid composition to soybean, poor in sulfur containing essential amino acid (methionine and cysteine), but rich in lysine (Naeem et al., 2016) (Table 1).

Germination of beans is a physicochemical process due to metabolism processes (Winarno, 1993). When water penetrates the seed, respiration, protein synthesis, and other metabolic process will be initiated. After a certain period, the embryo will emerge from the seed, signed with the appearance of radicle or hypocotyl in the surface of the seed. The sprout of the seed will emerge because of the elongation of hypocotyl as it pushes cotyledon to the surface (Bewley and Black, 1983). During the germination process, the starch content is converted into smaller parts of glucose and maltose. Glucose and fructose content increases by tenfold and sucrose by twofold. Protein molecule will break down into amino acids, which are lysine (24\%), threonine (19\%), and phenylalanine (7\%). The larger fat molecules will also be hydrolyzed into shorter fatty acids, which are easily digestible. Some minerals such as $\mathrm{Ca}$ and Fe that were in the bounded state will be released increasing bioavailability of the mineral (Winarno, 1993). Overall germination of lablab bean will significantly increase the value of protein, due to activation of hydrolytic enzyme. Germination will also reduce the complex carbohydrate content and inactivate trypsin inhibitor enzyme, resulting in better digestibility of nutrient (Osman, 2007).

Milk is an oil in water emulsion that includes soluble content. Water content in milk is very high (87.5\%) with specific milk sugar (lactose) of $5 \%$, protein of $3.5 \%$, and fat around $3-5 \%$. Milk is a very good source of calcium, phosphorus, and vitamin A (Csighy et al., 2018). Milk from animals contains lactose that cannot be digested properly by people with lactose intolerance condition. As an alternative, vegetable milk is created by extracting the milk from vegetable products, mixing it with water and continuing with filtration and pasteurization. Commonly used materials are legumes due to high protein content and similar amino acid composition as animal milk, making it a good substitute for some people.

Table 1. Chemical composition of 100 gr lablab bean

\begin{tabular}{lc}
\hline Component & Amount \\
\hline Protein $(\mathrm{g})$ & 21.5 \\
Fat $(\mathrm{g})$ & 1.2 \\
Carbohydrate $(\mathrm{g})$ & 61.4 \\
Fiber (g) & 6.8 \\
Ca (mg) & 98 \\
Fe (mg) & 149 \\
\hline
\end{tabular}

Source: Duke (1983). 


$$
2 \mathrm{HCl}_{(\mathrm{aq})}+\mathrm{CaCO}_{3(\mathrm{~s})} \rightarrow \mathrm{CaCl}_{2(\mathrm{aq})}+\mathrm{CO}_{2(\mathrm{~g})}+\mathrm{H}_{2} \mathrm{O}_{(\mathrm{l})}
$$

Fig. 1. Eggshell calcium chloride production. Source: Garnjanaggonchorn (2007)

Eggshell is a common food waste that is produced by poultry, household, and industry (King, 2011). Eggshell contains $98.2 \%$ calcium carbonate and trace components such as boron, copper, iron, manganese, molybdenum, sulfur, silicon, and zinc (Romanoff and Romanoff, 1949). Calcium carbonate from eggshell is a great natural source for calcium and far better than the limestone extracted calcium. The calcium composition of eggshell is very similar to that in the human body, such as in teeth and bones. Consumption of eggshell calcium can be one of the alternative solutions for calcium deficiency. A research by Guéguen and Pointillart (2000) studied the availability of organic and inorganic calcium sources, where they do not find significant difference in the availability of the mineral in human body. The mineral is said to be kept whole in body in order to fortify bone, teeth, and other human structures (Fig. 1).

The main problem of eggshell based calcium is that calcium carbonate is hard to absorb due to its low solubility. The extraction of calcium will utilize the reaction between salt and acid (Garnjanaggonchorn, 2007). Eggshell based calcium is a prospective product that can be very versatile in its usage, while reducing the amount of food waste. Utilization of eggshell based calcium as texture modifier had been studied and compared with conventional calcium source, for example in the form of sweet potato chips. Although it was successful, directly adding eggshell based calcium for the sake of fortification needs to be experimented even further (Tjandra et al., 2019). This paper will elaborate the results of eggshell based calcium on a product with a different form factor, liquid.

\section{METHODS}

Utensils that were used are digital weigh terminal (Mettler Toledo PG603-6), plastic bowls, plates, spoon, kitchen stove (Rinnai RI-522C), blender (Phillips HR2106), filter, and a wooden stirrer. Analysis utensils that were used are analytic weigh terminal (Mettler Toledo AT200M), beaker glass (Pyrex), measurement flask (Iwaki), glass burette, Erlenmeyer flask (Iwaki), hand refractometer (ATC THE01501 model), and pH meter (Extech PH100). The materials that are used were lablab bean and soya bean from the local Surabaya City Market (Indonesia), sugar (Gulaku), UHT milk (Ultramilk, Ultrajaya Brand), and distilled water. The materials that were used for analysis were EDTA 0.05M, Salmiac Buffer ( $\mathrm{pH} 10.0$ ), EBT (1:200), concentrate $\mathrm{H}_{2} \mathrm{SO}_{4}$, $\mathrm{NaOH} 10 \mathrm{~N}, \mathrm{Zn}$ powder, $\mathrm{H}_{2} \mathrm{C}_{2} \mathrm{O}_{4} 0.1 \mathrm{~N}, \mathrm{NaOH} 0.1 \mathrm{~N}, \mathrm{HCl} 0.1 \mathrm{~N}$, kjeldahl tablet, Methyl Red: Methyl Blue (1:2) indicator, and phenolphthalein indicator.

The experiment design was created to find the best germination time in order to create the optimal vegetable milk product. The variable that is chosen is protein digestibility. Randomized Block Design (RBD) is used with one factor (germination time) and five repetitions. Five germination times were used $(0,12,24,36,48 \mathrm{~h})$. The data from the experiment are tabulated and analyzed with ANOVA at $\alpha=5 \%$ and DMRT (Duncan Multiple Range Test) with the same confidence level. 


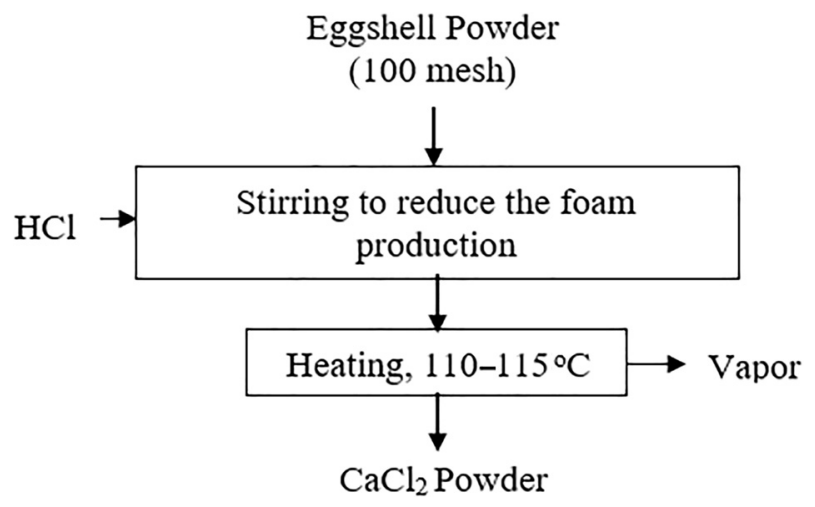

Fig. 2. Flow diagram of calcium chloride powder. Source: Garnjanagoonchorn (2007) with modification

Extraction of calcium was done by reacting calcium carbonate with $\mathrm{HCl} 2.5 \%(1: 25 \mathrm{w} / \mathrm{v})$ and stirred occasionally to reduce the production of foam. The solution is heated at $100-115{ }^{\circ} \mathrm{C}$ until it is dried and the resulting product will be calcium chloride powder (Garnjanagoonchorn, 2007) (Fig. 2).

The production of vegetable milk started with the pretreatment of lablab bean sprout. The sprouts were taken manually and the remaining beans are soaked in $\mathrm{NaHCO}_{3} 1 \%$ solution with the ratio of solution:bean $=4: 1$. The soaking was done for approximately $15 \mathrm{~min}$ in order to remove cyanide content of the bean. The extraction was done with the blender by the help of water 4 times of the beans weight. This process was done to get the filtrate of the bean. Mixing of $10 \% \mathrm{w} / \mathrm{v}$ sugar and $\mathrm{CaCl}_{2}$ powder followed by heating at $80-90^{\circ} \mathrm{C}$ for $15 \mathrm{~min}$ was carried out to get the final product. We also made soymilk with a similar formulation in order to compare the final composition between the two main ingredients. Despite the usage of commercial UHT milk, we decided to manufacture our own standardized soymilk. A similar experiment regarding vegetable milk had been carried out, and low amount of additives would affect the proximate composition and sensory acceptance (Kovács et al., 2009). UHT milk has received intensive treatment, and it is the standard of the calcium consumption that is aimed within this experiment. On one hand, soymilk is mainly used to compare the importance of raw legumes processing, and it will be more objective for the legumes to receive the same processing and treatment (Fig. 3).

The proximate analysis method for the protein digestibility used the Kjeldahl principle (AOAC, 2005). This is also the same method that was used to calculate the total protein content. Protein digestibility was measured by putting $1 \mathrm{~g}$ of crushed sprouted bean inside distilled water with 1:10 ratio $\mathrm{w} / \mathrm{v}$ for $30 \mathrm{~min}$ while being stirred slowly, and the solution was analyzed for protein content. Mineral content determination was done with titrimetric method of complexometry. Bivalent ion can be determined with the reaction with Ethylene Diamine Tetra Acetate (EDTA). The reaction was done at $\mathrm{pH} 10-11$ for better selectivity of Ca content. The reaction was carried out with Eriochrome Black T. (EBT 1:200) indicator by titrating $10 \mathrm{~mL}$ of sample with EDTA (Basset et al., 1989). pH value of samples was measured with $\mathrm{pH}$ meter that 


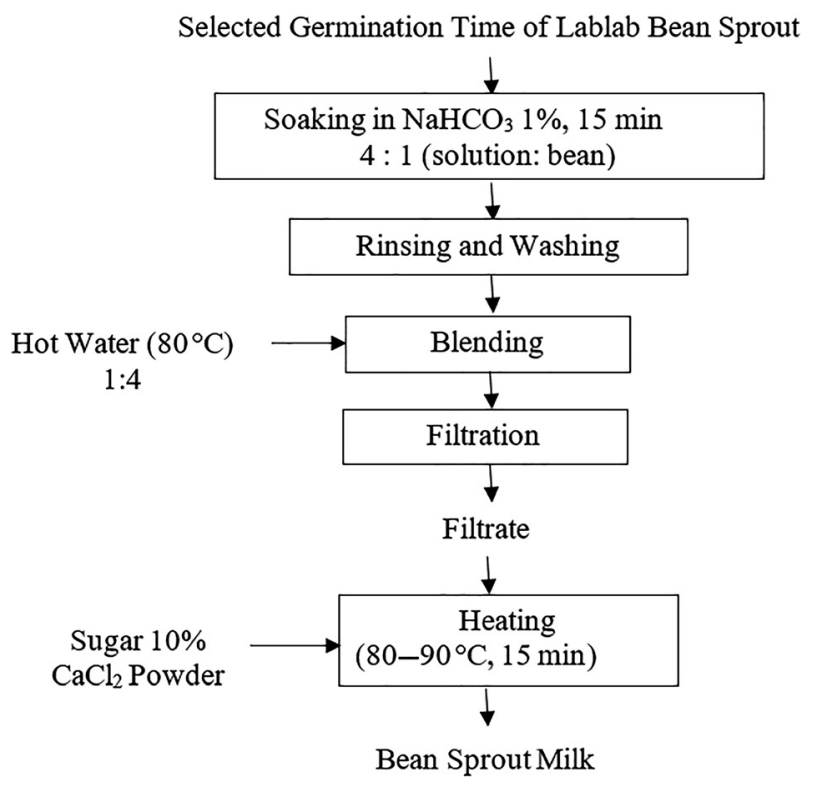

Fig. 3. Flow diagram of lablab bean sprout milk production

was standardized with buffer of $4.0 \mathrm{pH}$ and $10.0 \mathrm{pH}$. Total soluble solid content was measured with a hand refractometer and the unit of measurement is \% brix.

The results of the protein digestibility is plotted as the germination process is suspected to directly affect the soluble protein within the legumes. Therefore, choosing the germination time based on the digestible protein is more reasonable than choosing the time based on the total protein content, as the body will not be able to utilize the nutrient. Despite this, both the protein digestibility and the total protein content of the germinated bean will be plotted and compared in order to study the behavior of protein metabolism of the germinated lablab bean. The plots are done using Microsoft Excel running on a Windows personal computer operating system. Residual analysis and additional statistical tests were carried out in case there is some deviation from the constant variance. Breusch-Pagan Test for heteroscedasticity in linear regression is carried out, assuming homoscedasticity of data with the p-value below the appropriate threshold (in this experiment, it is $\mathrm{p}<0.05$ ). Additional statistical tests have been carried out in RStudio ver. 1.2.5001.

\section{RESULTS}

From the informal statistical test (residue analysis), it can be seen that the protein digestibility plot is not suitable to be regressed with the first order of regression, as the residual values show some distinct pattern (Fig. 4). This means that the model is not dependable to explain the variance from the regression. Breusch-Pagan test of the lablab bean protein content (Table 3) 

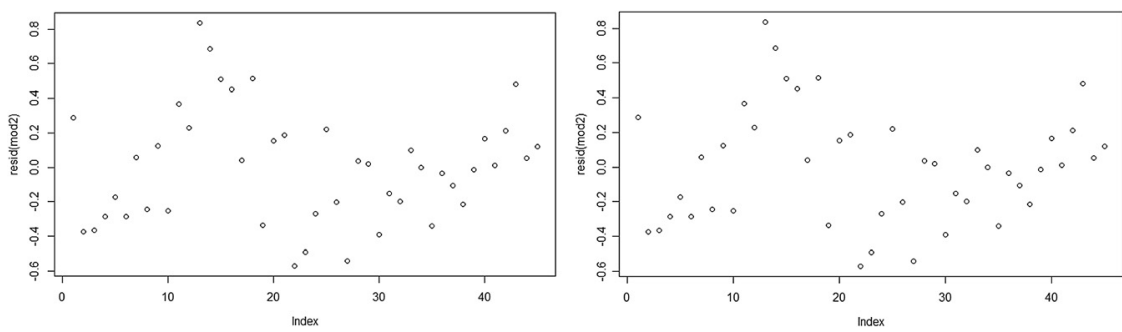

Fig. 4. Residual analysis of soluble protein content plot (Left: first order, Right: second order)

Table 2. Soluble protein of lablab bean sprout with various germination time

\begin{tabular}{lc}
\hline Germination time $(\mathrm{h})$ & Protein content $(\mathrm{g} / 100 \mathrm{~g})$ \\
\hline 0 & $10.09 \pm 0.62^{\mathrm{a}}$ \\
12 & $12.45 \pm 0.45^{\mathrm{b}}$ \\
24 & $12.49 \pm 0.51^{\mathrm{b}}$ \\
36 & $13.36 \pm 0.59^{\mathrm{c}}$ \\
48 & $13.39 \pm 0.66^{\mathrm{c}}$ \\
\hline
\end{tabular}

Notes: The value with the same superscript does not differ in DMRT $(P \leq 0.05)$

Table 3. Breusch-Pagan test for protein digestibility plot

\begin{tabular}{lccr}
\hline Regression model & Chi-square critical & Chi-square & p-value \\
\hline Order 1 & 3.84 & 9.24 & 0.0024 \\
Order 2 & 3.84 & 2.89 & 0.0889 \\
\hline
\end{tabular}

Table 4. Protein content of lablab bean milk and lablab bean sprout milk

\begin{tabular}{lc}
\hline Germination time $(\mathrm{h})$ & Protein content $(\mathrm{g} / 100 \mathrm{~g})$ \\
\hline 0 & $6.49 \pm 0.13^{\mathrm{a}}$ \\
12 & $6.73 \pm 0.19^{\mathrm{b}}$ \\
24 & $7.01 \pm 0.09^{\mathrm{c}}$ \\
36 & $7.21 \pm 0.06^{\mathrm{d}}$ \\
48 & $7.26 \pm 0.29^{\mathrm{d}}$ \\
\hline
\end{tabular}

Notes: The value with the same superscript does not differ in DMRT $(P \leq 0.05)$

tells us the value is below our threshold for the first order of regression, and is more suitable to the second order plot. The second order plot shows a respectable $R^{2}$ value of 0.9312 . For the total protein content, there is no problem with the regression model itself, as can be seen in Fig. 5 of the residual plot, but the $R^{2}$ value is lower $(0.8115)$. The protein content in the raw sprouted bean and the processed milk seems not to follow a linear trend. The protein synthesis shows reduction in slope after $24 \mathrm{~h}$ of germination, where it is almost flat around 36-48 h. Presumably, this is due to the lack of ingredients to be metabolized, thus halting the anabolic processes. 


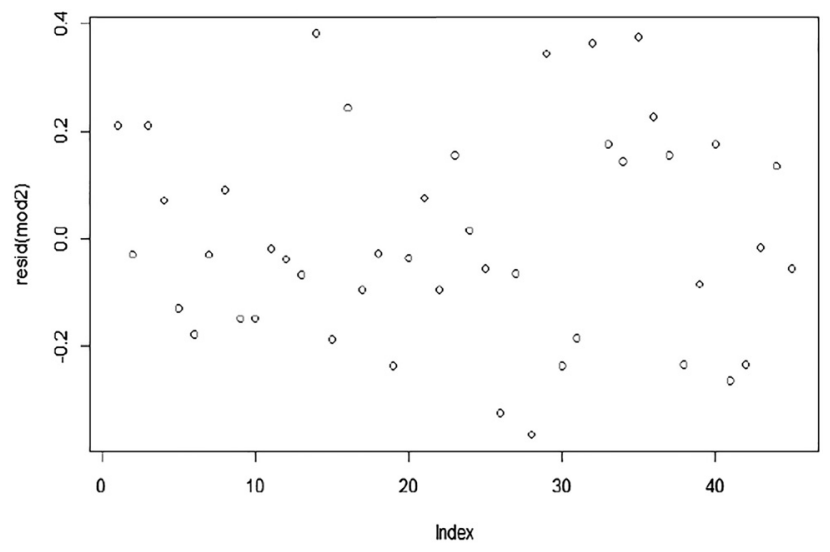

Fig. 5. Residual analysis of total protein content from germinated lablab bean milk

When processed, this lablab bean shows around $40 \%$ decrease in the soluble protein. This is due to the heat treatment within the vegetable milk processing, where $80^{\circ} \mathrm{C}$ deemed to be enough to denature almost half of the soluble protein.

Calcium content of lablab bean sprout milk was compared to other variants of milk (Table 5), namely the UHT Milk (Ultrajaya Brand), lablab bean sprout milk with the addition of $\mathrm{CaCl}_{2}$, lablab bean sprout milk without the addition of $\mathrm{CaCl}_{2}$, and soymilk (self-made with the same formulation as the lablab milk). It can be seen from the experiment that the addition of $\mathrm{CaCl}_{2}$ by $2 \% \mathrm{w} / \mathrm{v}$ is optimal to get a similar calcium content as the more familiar high-calcium containing UHT milk. The taste of the eggshell based calcium is a little bitter, but it is not as bitter as the commercial calcium chloride. There was also a faint hint of salty taste within the calcium. When mixed with this proportion, it was agreed by the panelists that this concentration is enough, from the sensory and composition perspective.

$\mathrm{pH}$ level (Table 6) was measured because of high phenol, flavonoid, and alkaloid content of the lablab bean. Lablab bean indicates more alkaline $\mathrm{pH}$ than other kinds of milk. The addition of $\mathrm{CaCl}_{2}$ powder did not change the $\mathrm{pH}$ drastically because $\mathrm{CaCl}_{2}$ is a salt, which derives from strong acid and strong base and has a neutral $\mathrm{pH}$. Total soluble solid content was analyzed in order to compare the soluble materials in the product (Table 7). Sugar content of commercial

Table 5. Calcium content of various kinds of milk

\begin{tabular}{lc}
\hline Variety & Calcium $(\mathrm{mg} / 100 \mathrm{~g})$ \\
\hline UHT & $299 \pm 0.46^{\mathrm{a}}$ \\
Lablab Bean Sprout Milk $+\mathrm{CaCl}_{2}$ & $276 \pm 0.13^{\mathrm{a}}$ \\
Lablab Bean Sprout Milk & $85 \pm 0.17^{\mathrm{b}}$ \\
Soymilk & $77 \pm 0.18^{\mathrm{b}}$ \\
\hline
\end{tabular}

Notes: The value with the same superscript does not differ in DMRT $(P \leq 0.05)$ 
Table 6. $\mathrm{pH}$ value of various kind of milk

\begin{tabular}{lc}
\hline Variety & pH \\
\hline UHT & $6.43 \pm 0.10^{\mathrm{a}}$ \\
Lablab Bean Sprout Milk $+\mathrm{CaCl}_{2}$ & $6.69 \pm 0.13^{\mathrm{a}}$ \\
Lablab Bean Sprout Milk & $6.74 \pm 0.17^{\mathrm{a}}$ \\
Soymilk & $6.77 \pm 0.18^{\mathrm{a}}$ \\
\hline
\end{tabular}

Notes: The value with the same superscript does not differ in DMRT $(P \leq 0.05)$

Table 7. Total soluble solid content of various kind of milk

\begin{tabular}{lr}
\hline Variety & $\%$ brix \\
\hline UHT & $12.5^{\mathrm{a}}$ \\
Soymilk & $12.5^{\mathrm{a}}$ \\
Lablab Bean Sprout Milk $+\mathrm{CaCl}_{2}$ & $19.0^{\mathrm{b}}$ \\
Lablab Bean Sprout Milk & $18.8^{\mathrm{b}}$ \\
\hline
\end{tabular}

Notes: The value with the same superscript does not differ in DMRT $(P \leq 0.05)$

soymilk is around $10-15 \%$, the same proportion used for the production of lablab bean and the sample soymilk. UHT milk does not contain any added sugar, but it contains milk specific sugar (lactose)

\section{DISCUSSION}

Protein digestibility indicates the amount of soluble protein inside the material. High amount of easily soluble protein is favorable. Germination process breaks down larger protein molecules and increases its digestibility. From the experiment result, there is a definite increase in protein digestibility during germination process, which can be seen in Table 2 . The germination time of $36 \mathrm{~h}$ was selected because it does not differ from the longer germination time ( $48 \mathrm{~h}$ ) but will be more optimal in terms of time. Protein content of milk was then analyzed by comparing the protein content from normal vegetable lablab bean milk and lablab bean sprout milk with $36 \mathrm{~h}$ of germination time. It can be seen that germination process still exhibits increase in the protein content due to protein synthesis of germination. The protein content of milk can be seen in Table 4. The protein content is lower than the ingredient itself (raw bean sprout) because the milk undergoes heating process (pasteurization) and some protein was denatured.

\section{CONCLUSION}

Lablab bean is a prominent bean commonly found in Asia and can be utilized as a value added product. Germination of lablab bean was able to increase the overall nutritional quality of the bean. The germination time of $36 \mathrm{~h}$ was chosen and produced the most optimal product timewise with the protein content of $13.36 \pm 0.59 \mathrm{~g} / 100 \mathrm{~g}$. Lablab bean sprout milk germinated for 36 
h contains $7.21 \pm 0.06 \mathrm{~g} / 100 \mathrm{~g}$ protein, $19.0 \%$ brix total soluble solid content, and $\mathrm{pH}$ value of $6.74 \pm 0.17$. Lablab bean sprout milk does not contain much calcium, so it was fortificated with eggshell extracted calcium in the form of calcium chloride powder. The powder was added $2 \%$ $(\mathrm{w} / \mathrm{v})$ and yields the calcium content rivaling commercial milk $276 \pm 0.13 \mathrm{mg} / 100 \mathrm{~g}$.

\section{RECOMMENDATIONS}

The condition for germination such as gas, light, temperature, and other external-internal factors might affect the germination process and the product it yields. Further study is needed to analyze these effects. Protein profiling of the germinated bean might be interesting to give an in depth view of the germination kinetic. The behavior of eggshell based calcium for direct human consumption also needs more in depth in-vivo study of metabolism.

\section{REFERENCES}

AOAC. (2005). Determination of moisture, ash, protein and fat. Official method of analysis of the association of analytical chemists, 18th Edition, AOAC, Washington DC.

Basset, J, Jeffery, G.H., Mendham, J., and Denney, R.C. (1989). Vogel's textbook of quantitative chemical analysis. John Wiley \& Sons Inc., USA, p. 69. ISBN: $9780582446939-0582446937$.

Bewley, J.D. and Black, M. (1983). Physiology and biochemistry of seeds in relation to germination. Springer, New York, p. 62.

Csighy, A., Koris, A., and Vatai, G. (2018). Diafiltration based cow's milk partial demineralization by membrane filtration process - parameter and technology estimations. Progress, 14(s1): 45-55.

Duke, J.A. (1983). Handbook of legumes of world economic importance. Plenum Press, New York, p. 103, https://doi.org/10.1007/978-1-4684-8151-8.

Garnjanagoonchorn, W. (2007). Preparation and partial characterization of eggshell calcium chloride. International Journal of Food Properties, 10, 497-503.

Guéguen, L. and Pointillart, A. (2000). The bioavailability of dietary calcium. Journal of the American College of Nutrition, 19: 119S-136S. https://doi.org/10.1080/07315724.2000.10718083.

Kay, D.E. (1979). Food legumes. Tropical Products Institute, London, p. 233.

King, A.M. (2011). A review of the uses of poultry eggshells and shell membranes. International Journal of Poultry Science, 10(11): 908-912.

Kovács, Z., Szöllősi, D., and Fekete, A. (2009). Application of electronic tongue to soya drink discrimination. Progress, 5(1): 75-96.

Naeem, M., Khan, M.M.A., and Uddin, M. (2016). Hyacinth bean (Lablab purpureus (L.) Sweet): A hidden treasure of useful phytochemicals. Legume Perspectives, 13:29-32. ISSN 2340-1559.

Osman, M.A. (2007). Changes in nutrient composition, trypsin inhibitor, phytate, tannins, and protein digestibility of dolichos lablab seeds (Lablab purpureus (L.) Sweet) occurring during germination. Journal of Food Technology, 5: 294-299.

Purseglove, J.W., Brown, E.G., Green, C.L., and Robins, S.R.J. (1981). Spices, Vol. 1. Longman Inc, New York.

Romanoff, A.L. and Romanoff, A.J. (1949). The avian egg. John Wiley \& sons, Inc, New York. 
Salunke, D. K., Kadam, S.S. and Chafan, J.K. (1985). Postharvest biotechnology of food legumes. CRC Press, Boca Raton, FL, p. 83.

Tjandra, D., Suseno, T., Ristiarini, S., and Jati, I. (2019). Physicochemical Characteristics of Sweet Potato

(Ipomoea batatas L.) Chips Pre-treated by Commercial and Eggshell Extracted Calcium Chloride. IOP

Conference Series: Earth and Environmental Science, 255: 012011. https://doi.org/10.1088/1755-1315/ 255/1/012011.

Winarno, F.G. (1993). Pangan Gizi Teknologi dan Konsumen. Gramedia Pustaka Utama, Jakarta, p. 320.

\section{APPENDIX}

Personal Documentation of Lablab Bean Sprout Milk Production

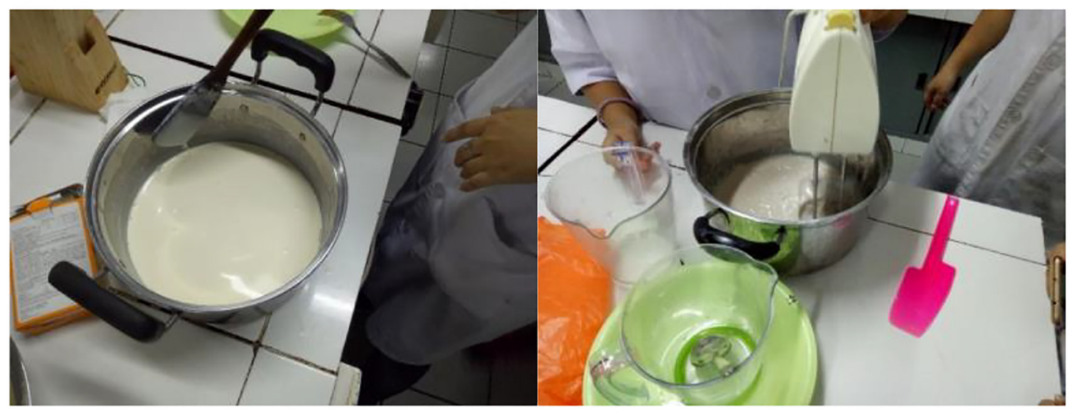

Final prototype of the formulation

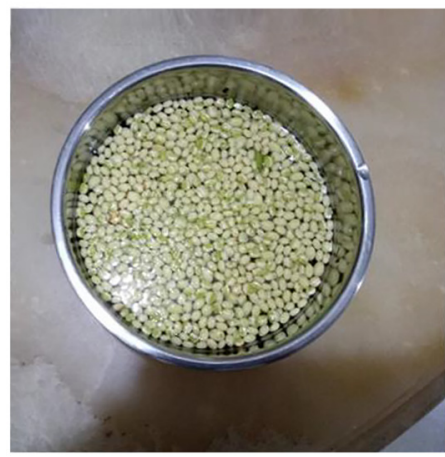

Sodium bicarbonate soaking

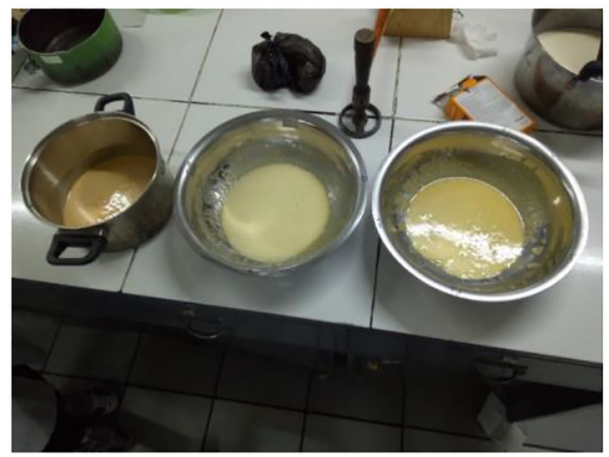

Odd-colored prototypes from the formulation

Open Access. This is an open-access article distributed under the terms of the Creative Commons Attribution 4.0 International License (https://creativecommons.org/licenses/by/4.0/), which permits unrestricted use, distribution, and reproduction in any medium, provided the original author and source are credited, a link to the CC License is provided, and changes - if any - are indicated. (SID_1) 